\title{
Bio-efficacy of Different Strains of Bacillus spp. against Meloidogyne incognita under in vitro
}

\author{
H.S. Mahesha ${ }^{1 *}$, N.G. Ravichandra ${ }^{1}$, M.S. Rao ${ }^{3}$, N.C. Narasegowda ${ }^{2}$, \\ Shreeshail Sonyal ${ }^{1}$ and Shivalingappa Hotkar ${ }^{4}$
}

\author{
${ }^{1}$ Department of Plant Pathology, ${ }^{2}$ Department of Horticulture, UAS, GKVK, \\ Bengaluru, Karnataka, India \\ ${ }^{3}$ Division of Entomology and Nematology, IIHR, Bengaluru, Karnataka, India \\ ${ }^{4}$ Department of Plant Pathology, ARS, Nipani, UAS, Dharwad, Karnataka, India \\ *Corresponding author
}

\begin{tabular}{|c|c|}
\hline & A B S T R A C T \\
\hline & \multirow{6}{*}{$\begin{array}{l}\text { Root-knot nematode caused by Meloidogyne incognita is the major constraints in } \\
\text { production of tomato and other solanaceous crops. Nematode diseases have been } \\
\text { controlled more recently by means of certain beneficial bacteria that are indigenous to the } \\
\text { rhizosphere of plants. Among the PGPR, Bacillus spp. is very important bio-agent that has } \\
\text { several benefits compared to other rhizobacteria. Biological control is free from residual } \\
\text { and adverse environmental effects. Hence, biological control is gaining more importance } \\
\text { in the recent decades. Different concentrations culture filtrates of Bacillus spp. were tested } \\
\text { for their efficacy on egg hatching inhibition of } M \text {. incognita under in vitro conditions. All } \\
\text { the species had significant effect on egg hatching inhibition. However, maximum } \\
\text { suppression of egg hatching was observed in case of B. pumilus-K-1 }(94.18 \% \text { ), followed } \\
\text { by B. megaterium-IIHR ( }(92.93 \%), B \text {. subtilis-IIHR ( }(90.43 \%) \text { and B. subtilis-P-203 ( } 92.09 \\
\% \text { ) in } 100 \text { per cent concentration at } 120 \text { hours after treatment. }\end{array}$} \\
\hline & \\
\hline $\begin{array}{l}\text { Bacillus spp. and } M \text {. } \\
\text { incognita. }\end{array}$ & \\
\hline Article Info & \\
\hline $\begin{array}{l}\text { Accepted: } \\
\text { 20 September } 2017 \\
\text { Available Online: } \\
10 \text { November } 2017\end{array}$ & \\
\hline & \\
\hline
\end{tabular}

\section{Introduction}

Tomato (Solanum lycopersicum L.) is one of the most popular vegetable crops grown in the world, next to potato. In India, tomato is being grown in about 0.87 million hectares with an annual production of 18.22 million tones. In Karnataka, it is cultivated in an area of $0.061 \mathrm{~m}$ ha with production of 2.06 million tones. Tomato crop is affected by many fungal, bacterial, viral and nematode pathogens. Among them, Root-knot nematode caused by Meloidogyne incognita (Kofoid \& White) Chitwood is the major constraints in production of tomato and other solanaceous crops. The root-knot nematode (Meloidogyne spp.) is sedentary endoparasites and is among the most damaging agricultural pest. The damage potential of $M$. incognita in tomato is as high as 27.20 per cent yield loss in India (Jain et al., 2007).

In majority of the wilt complex interaction, $M$. incognita acts as a predisposing agent for the entry of bacterium resulting in increased severity of wilt. Further, it leads to resistance break down very quickly in presence of $M$. incognita is a problem (Jatala et al., 1975). 
Although disease resistance is an important component of integrated disease management, resistance breaks down in the resistant variety very quickly in presence of $M$. incognita (Jatala et al., 1975). However, the potential negative impact on environment and ineffectiveness after prolonged use have led to a total ban or restricted use of most chemical nematicides and an urgent need for safe and more effective alternatives (Zukerman and Esnard, 1994). Among the PGPR, Bacillus spp. is very important bioagent that has several benefits compared to other rhizobacteria. It has very good antagonistic activity against many soil borne pathogens of fungal, bacterial and plant parasitic nematodes. To achieve success, it is essential that bacteria establish, survive and proliferate in the soil (Dinesh et al., 2012). Many species of Pseudomonas and Bacillus have been reported as plant growth promoting rhizobacteria (PGPR) producing ironchelating siderophores, antibiotics or hydrogen cyanide, and these compounds have been implicated in the reduction of deleterious and pathogenic rhizosphere microorganisms, creating an environment more favourable for root growth (Siddiqui and Mahmood, 2006). So that the effort was made to identify the good antagonistic bacteria against suppression of nematode egg hatching.

\section{Materials and Methods}

\section{In vitro evaluation of different strains/ species of Bacillus on Meloidogyne incognita}

The study was done to know the bio efficacy of Bacillus spp. on egg hatching of $M$. incognita. Three strains of Bacillus subtilis (Bs-IIHR, Bs-NER-51, Bs-P-203), one strain of Bacillus megaterium (Bm-IIHR), one strain of Bacillus amyloliquefaciens (Ba-NER-41), two strains of Bacillus pumilus (Bp-K1, Bp-6) were used in this study; different concentration of culture filtrates was prepared as follows and distilled water served as control.

\section{Preparation of bioagents concentrations}

One hundred $\mathrm{ml}$ of nutrient broth was prepared and sterilized. A loop full of bio agent inoculum was aseptically transferred to broth and incubated at room temperature i.e. $28{ }^{\circ} \mathrm{C}$ for $48 \mathrm{~h}$. After incubation, culture filtrates were harvested by centrifuging the broth at $6000 \mathrm{rpm}$ for 15 minutes at $4{ }^{\circ} \mathrm{C}$ and supernatant was passed through $0.22 \mu \mathrm{m}$ syringe filters. Filtrates were collected in sterilized plastic tubes, which were used as a stock solution of hundred per cent concentration. Diluted the stock culture filtrates to 75,50 and 25 per cent concentration by using sterile distilled water.

\section{Collection of egg masses of $M$. incognita}

M. incognita infected tomato roots were washed under gentle stream of water to remove soil adhering to the root. Uniform sized egg masses were handpicked carefully from the galls with the help of forceps. The collected egg masses were transferred to a sterile Petri plate containing sterile water.

\section{Effect on egg hatching}

Five equal sized fresh egg masses of $M$. incognita collected from infected tomato roots were placed in $3 \mathrm{ml}$ of culture filtrates in different dilutions in sterilized $5 \mathrm{~cm}$ Petri plates and incubated at room temperature. The Petri dish having sterile water served as control. Each treatment was replicated thrice. The plates were examined under microscope after 24, 48, 72, 96 and $120 \mathrm{~h}$ for hatching of eggs and the number of eggs hatched were counted at each interval. After $120 \mathrm{~h}$, egg masses were transferred to sterile water and number of eggs hatched was counted at every $24 \mathrm{~h}$ interval up to $72 \mathrm{~h}$. Culture filtrates 
treated egg masses were stained using acid fuchisin. The inhibition of the egg hatching rate was calculated using to the formula:

$\mathrm{I}(\%)=(\mathrm{C}-\mathrm{T}) / \mathrm{C} \times 100$,

Where,

I- the inhibition of the egg hatching,

T-Number of eggs hatched or number juveniles in suspension in treatment

C- Number of eggs hatched or number juveniles in suspension in the control

\section{Results and Discussion}

\section{Studies on inhibition of egg hatching}

The effect of four concentrations of different strains of Bacillus spp. viz., 25, 50, 75 and 100 per cent were tested for their ability to inhibit egg hatching of $M$. incognita under in vitro.

\section{At 24 hours after treatment}

At 25 per cent concentration, egg hatching by different strains of Bacillus spp. ranged from 31.33 to 51.67 (Table 1). The minimum egg hatching was observed in B. megateriumIIHR (31.33) amounting to 67.02 per cent inhibition followed by $B$. pumilus-K-1 (34.00), B. subtilis- P-203 (34.67) and $B$. subtilis- IIHR (36.33) amounting to 64.21, 63.50 and 61.75 per cent inhibition, respectively and they were on par with each other. However, maximum egg hatching was observed in B. pumilus-6 (51.67) followed by $B$. amyloliquefaciens-NER-41 (45.67) and $B$. subtilis-NER-51 (45.00) amounting to 45.61, 51.92 and 52.63 per cent suppression as compared to control. At 50 per cent concentration, egg hatching ranged from 24.00 to 47.67 . Minimum egg hatching was observed in B. megaterium- IIHR (24.00) amounting to 74.73 per cent inhibition as compared to control and maximum egg hatching was observed in $B$. pumilus-6 (47.67) amounting to 49.82 per cent inhibition. $B$. pumilus-K-1(25.00) and $B$. subtilis- P-203 (26.33) amounting to 73.68 and $72.28 \%$ inhibition, they were on par with each other. However, B. pumilus-6 (47.67); B. subtilis-IIHR (32.33) inhibition; $B$. amyloliquefaciens-NER-41 (35.33) and $B$. subtilis-NER-51 (39.33) amounting to 49.82, 65.96, 62.81 and 58.60 per cent inhibition as compared to untreated control. All the strains significantly reduced egg hatching as compared to untreated control at 75 per cent concentration. The minimum egg hatching was observed in B. pumilus-K-1 (15.67) amounting to 83.50 per cent inhibition followed by $B$. megaterium- IIHR (16.67) and B. subtilis- P-203 (17.67) amounting to 82.45 and 81.40 per cent inhibition at 75 per cent concentration, respectively. Maximum egg hatching was observed in $B$. pumilus-6 (27.67) amounting to 70.87 per cent inhibition followed by $B$. subtilis-NER-51 (27.67), $B$. amyloliquefaciens-NER-41 (21.67) and $B$. subtilis- IIHR (20.33) amounting to 70.87, 77.18 and 78.60 per cent inhibition over untreated control,.

Egg hatching among the different strains of Bacillus spp. ranged from 6.33 to 18.67 at 100 per cent concentration. The minimum egg hatching was observed in $B$. pumilus-K1(6.33) amounting to 93.33 per cent inhibition followed by $B$. megaterium-IIHR (9.00); $B$. subtilis- IIHR (9.33) and B. subtilis- P-203 (10.67) amounting to $90.52,90.17$ and 88.72 per cent inhibition respectively, they were superior over rest of the strains. Maximum egg hatching of 18.67 was observed in $B$. pumilus-6 followed by $B$. subtilis-NER-51 (17.67) and $B$. amyloliquefaciens-NER-41 (13.00) amounting to 80.34, 81.40 and 86.31 per cent inhibition respectively. 
Table.1 Inhibition of egg hatching of M. incognita by culture filtrates of Bacillus spp.

\begin{tabular}{|c|c|c|c|c|c|c|c|c|}
\hline \multirow[b]{2}{*}{ Treatments } & \multicolumn{8}{|c|}{ Egg hatching after 24 hours of treatment in different concentrations of culture filtrates } \\
\hline & $25 \%$ & $\begin{array}{c}\text { Per cent } \\
\text { Inhibition over } \\
\text { control }\end{array}$ & $\mathbf{5 0 \%}$ & $\begin{array}{c}\text { Per cent } \\
\text { Inhibition over } \\
\text { control }\end{array}$ & $75 \%$ & $\begin{array}{c}\text { Per cent } \\
\text { Inhibition over } \\
\text { control }\end{array}$ & $100 \%$ & $\begin{array}{c}\text { Per cent } \\
\text { Inhibition over } \\
\text { control }\end{array}$ \\
\hline $\mathrm{T}_{1}=$ Bacilluspumilus $-\mathrm{K}-1$ & 34.00 & 64.21 & 25.00 & 73.68 & 15.67 & 83.50 & 6.33 & 93.33 \\
\hline $\mathrm{T}_{2}=$ B.subtilis-IIHR & 36.33 & 61.75 & 32.33 & 65.96 & 20.33 & 78.60 & 9.33 & 90.17 \\
\hline $\mathrm{T}_{3}=$ B.megaterium -IIHR & 31.33 & 67.02 & 24.00 & 74.73 & 16.67 & 82.45 & 9.00 & 90.52 \\
\hline $\mathrm{T}_{4}=$ B.pumilus -6 & 51.67 & 45.61 & 47.67 & 49.82 & 27.67 & 70.87 & 18.67 & 80.34 \\
\hline $\mathrm{T}_{5}=$ B.subtilis $-\mathrm{NER}-51$ & 45.00 & 52.63 & 39.33 & 58.60 & 27.67 & 70.87 & 17.67 & 81.40 \\
\hline $\mathrm{T}_{6}=$ B.subtilis $-\mathrm{P}-203$ & 34.67 & 63.50 & 26.33 & 72.28 & 17.67 & 81.40 & 10.67 & 88.76 \\
\hline $\begin{array}{l}\mathrm{T}_{7}=\text { B. amyloliquefaciens } \text {-NER- } \\
41\end{array}$ & 45.67 & 51.92 & 35.33 & 62.81 & 21.67 & 77.18 & 13.00 & 86.31 \\
\hline $\mathrm{T}_{8}=$ Untreated & 95.00 & 0.00 & 95.00 & 0.00 & 95.00 & 0.00 & 95.00 & 0.00 \\
\hline \multirow[t]{2}{*}{ SEm \pm} & \multicolumn{3}{|c|}{$\mathbf{T}$} & \multicolumn{3}{|c|}{$\mathbf{C}$} & \multicolumn{2}{|r|}{$\mathbf{T} \times \mathbf{C}$} \\
\hline & \multicolumn{3}{|c|}{2.152} & \multicolumn{3}{|c|}{1.627} & \multicolumn{2}{|r|}{4.304} \\
\hline CD @ 1 \% level & \multicolumn{3}{|c|}{5.740} & \multicolumn{3}{|c|}{4.339} & \multicolumn{2}{|r|}{11.481} \\
\hline
\end{tabular}

Table.2 Inhibition of egg hatching of M. incognita by culture filtrates of Bacillus spp.

\begin{tabular}{|c|c|c|c|c|c|c|c|c|}
\hline \multirow[b]{2}{*}{ Treatments } & \multicolumn{8}{|c|}{ Egg hatching after 120 hours of treatment in different concentrations of culture filtrates } \\
\hline & $25 \%$ & $\begin{array}{c}\text { Per cent } \\
\text { Inhibition } \\
\text { over } \\
\text { control }\end{array}$ & $\mathbf{5 0 \%}$ & $\begin{array}{c}\text { Per cent } \\
\text { Inhibition over } \\
\text { control }\end{array}$ & $75 \%$ & $\begin{array}{c}\text { Per cent } \\
\text { Inhibition over } \\
\text { control }\end{array}$ & $100 \%$ & $\begin{array}{c}\text { Per cent } \\
\text { Inhibition over } \\
\text { control }\end{array}$ \\
\hline $\mathrm{T}_{1}=$ Bacilluspumilus $-\mathrm{K}-1$ & 45.33 & 71.72 & 37.67 & 76.50 & 25.50 & 84.09 & 9.33 & 94.18 \\
\hline $\mathrm{T}_{2}=$ B. subtilis -IIHR & 47.67 & 70.27 & 46.67 & 70.89 & 27.33 & 82.95 & 15.33 & 90.43 \\
\hline $\mathrm{T}_{3}=B$. megaterium $-\mathrm{IIHR}$ & 47.00 & 70.68 & 41.33 & 74.22 & 25.67 & 83.98 & 11.33 & 92.93 \\
\hline $\mathrm{T}_{4}=$ B.pumilus -6 & 76.67 & 52.17 & 66.33 & 58.62 & 49.33 & 69.23 & 31.33 & 80.45 \\
\hline $\mathrm{T}_{5}=$ B. subtilis-NER-51 & 62.33 & 61.12 & 52.67 & 67.14 & 36.00 & 77.54 & 22.67 & 85.86 \\
\hline $\mathrm{T}_{6}=$ B. subtilis-P-203 & 46.67 & 70.89 & 44.33 & 72.35 & 27.67 & 82.74 & 12.67 & 92.09 \\
\hline $\mathrm{T}_{7}=$ B. amyloliquefaciens -NER-41 & 67.33 & 58.00 & 56.67 & 64.65 & 36.33 & 77.34 & 20.33 & 87.31 \\
\hline $\mathrm{T}_{8}=$ Untreated & 160.33 & 0.00 & 160.33 & 0.00 & 160.33 & 0.00 & 160.33 & 0.00 \\
\hline \multirow[t]{2}{*}{ SEm \pm} & \multicolumn{3}{|c|}{$\mathbf{T}$} & \multicolumn{3}{|c|}{$\mathrm{C}$} & \multicolumn{2}{|r|}{$\mathbf{T} \times \mathbf{C}$} \\
\hline & \multicolumn{3}{|c|}{2.215} & \multicolumn{3}{|c|}{1.674} & \multicolumn{2}{|r|}{4.430} \\
\hline CD@ $1 \%$ level & \multicolumn{3}{|c|}{5.907} & \multicolumn{3}{|c|}{4.465} & \multicolumn{2}{|r|}{11.815} \\
\hline
\end{tabular}


Fig.1 Effect of culture filtrates of B. pumilus-K-1 and B. megaterium-IIHR on M. incognita eggs

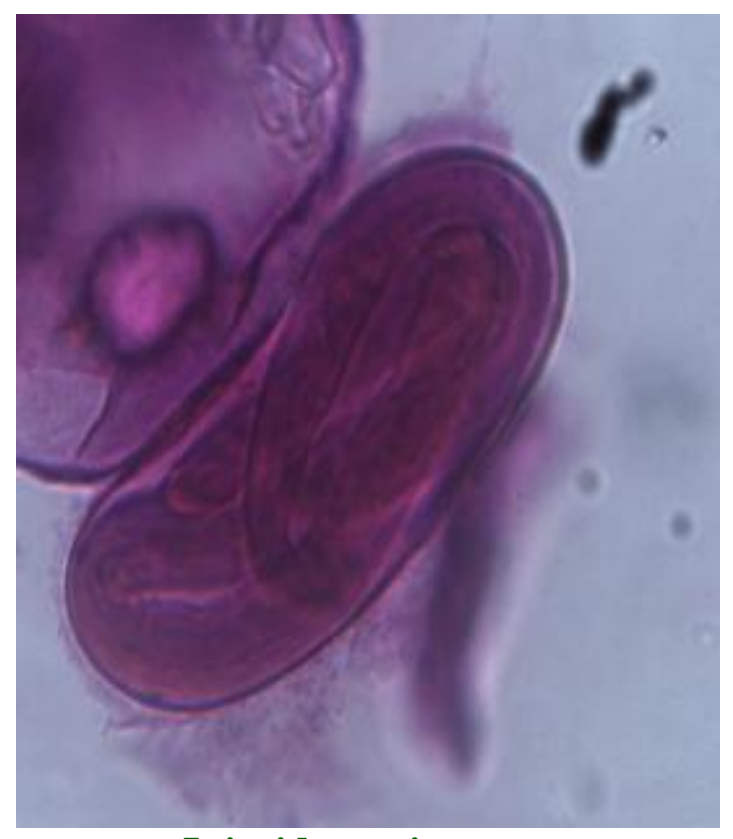

$\mathbf{J}_{1}$ inside egg in water

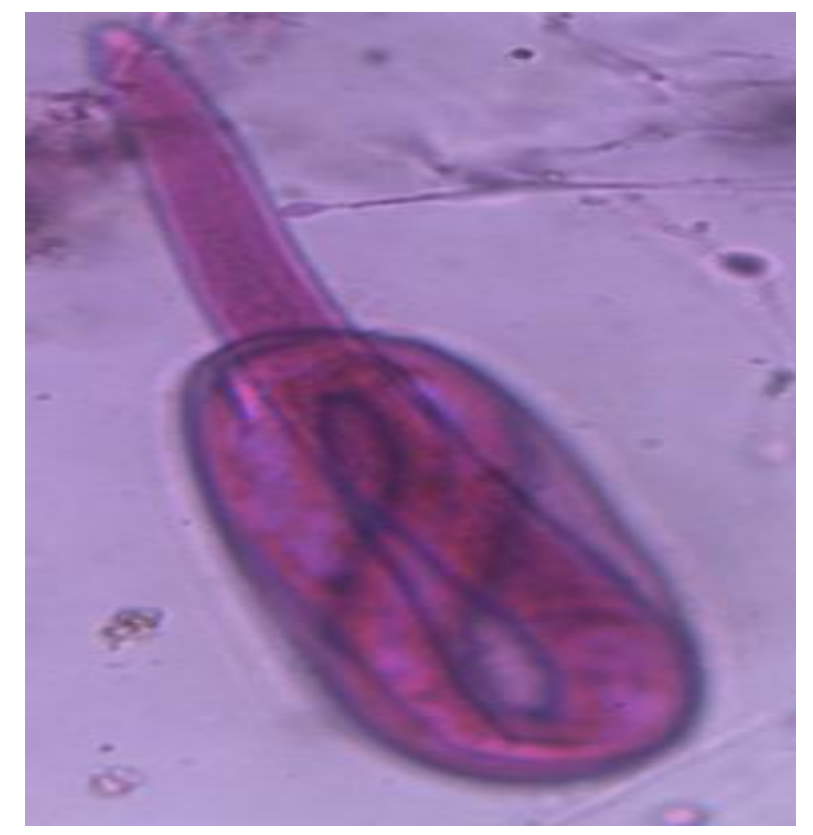

$\mathbf{J}_{2}$ emerging from egg in water

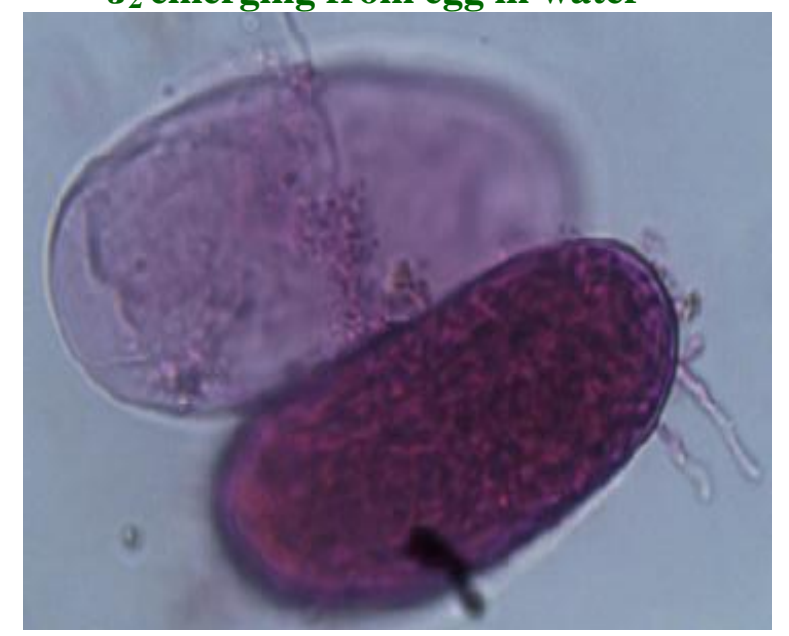

Degraded $\mathrm{J}_{1}$ inside the egg after treatment

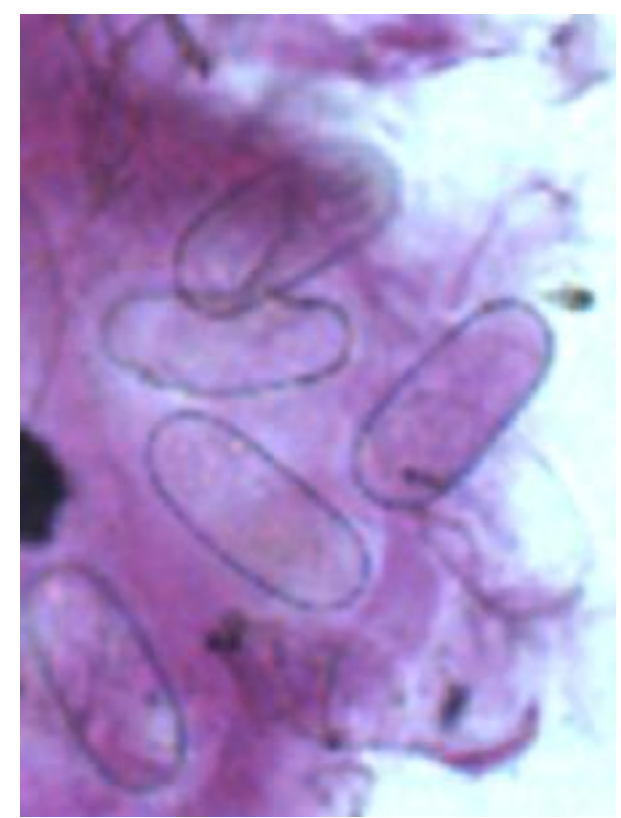

Empty egg shell after emergence 
Similar findings were obtained by Kavitha et al., (2012) identified three families of Bacillus lipopeptides (surfactins, iturins and fengycins). Six antagonistic endophytic strains of B. subtilis viz., Bs N 1, Bs N 3, Bs $\mathrm{N} 4$, Bs N 7, Bs 5 and Bs N 11, were isolated from noni plants and tested for their nematicidal activity against $M$. incognita. The Bacillus strains with high surfactin and iturin activity, suppressed hatching of eggs and killed second stage juveniles of the nematode under in vitro conditions.

\section{At $120 \mathrm{~h}$ after treatment}

Egg hatching by Bacillus spp. was recorded at $120 \mathrm{~h}$ after treatment and data are presented in Table 2. At 25 per cent concentration, egg hatching among the Bacillus strains ranged from 45.33 to 76.67 . The minimum egg hatching was observed in B. pumilus-K-1 (45.33) followed by $B$. subtilis- P-203 (46.67); B. megaterium- IIHR (47.00) and $B$. subtilis- IIHR (47.67) amounting to 71.72, $70.89,70.68$ and 70.27 per cent inhibition respectively and they were on par with each other.

However, maximum egg hatching was observed in case of B. pumilus-6 (76.67) followed by $B$. amyloliquefaciens-NER-41 (67.33) and B. subtilis-NER-51 (62.33) amounting to $52.17,58.00$ and 61.12 per cent inhibition, respectively.

Egg hatching among the Bacillus strains ranged from 37.67 to 66.33 at 50 per cent concentration. The minimum egg hatching was observed in case of $B$. pumilus-K1(37.67) amounting to $76.50 \%$ inhibition as compared to control (0.00 per cent) and maximum egg hatching was observed in $B$. pumilus-6 (66.33) amounting to 58.62 per cent. $B$. megaterium- IIHR (41.33), $B$. subtilis- P-203 (44.33) and B. subtilis- IIHR (46.67) amounting to $74.22,72.35$ and 70.89 per cent inhibition respectively, they were on par with each other. However, $B$. amyloliquefaciens-NER-41 (56.67) and $B$. subtilis-NER-51 (52.67) amounting to 64.65 and 64.65 per cent inhibition respectively. All the strains significantly reduced egg hatching as compared to untreated control.

The minimum egg hatching was observed in $B$. pumilus-K-1(25.50) followed by $B$. megaterium- IIHR (25.67) and B. subtilisIIHR (27.33) amounting to $84.09,83.78$ and 81.40 per cent suppression at 75 per cent concentration. Maximum egg hatching was observed in B. pumilus-6 (49.33) followed by B. subtilis-NER-51 (36.00), B. amyloliquefaciens-NER-41 (36.33) and $B$. subtilis- P-203 (27.67), amounting to 69.23, $77.54,77.34$ and 82.74 per cent inhibition of egg hatching.

At 100 per cent concentration, the minimum egg hatching was observed in B. pumilus-K-1 (9.33) represented in fig. 1, they were on par with the $B$. megaterium- IIHR (11.33), $B$. subtilis-P-203 (12.67) and B. subtilis- IIHR (15.33) amounting to $94.18,92.93,92.09$ and 90.17 per cent suppression respectively, they were on par with each other, but superior over the rest of the strains. Maximum egg hatching was observed in B. pumilus-6 (31.33) followed by $B$. subtilis-NER-51 (22.67) and B. amyloliquefaciens-NER-41 (20.33) amounting to $80.45,85.86$ and 87.31 per cent inhibition respectively. In general, in all four concentrations $B$. pumilus-K-1, B. subtilis-P203 and $B$. megaterium-IIHR significantly suppressed the egg hatching of $M$. incognita at $120 \mathrm{~h}$ after treatment. These results are similar with the findings of Ying et al., (2010) who reported Bacillus spp. culture could significantly inhibiting the hatching of eggs and increases the mortality of second stage juveniles and reduce infection of the nematode through production of nematicidal volatiles. 


\section{References}

Dinesh, S., Yadav, D.K., Shweta S. and Upadhyay, B. K., 2012. Utilization of plant growth promoting Bacillus subtilis isolates for the management of bacterial wilt incidence in tomato caused by Ralstonia solanacearum Race 1 Biovar 3. Indian Phytopathol, 65(1): 18-24.

Jain, R.K., Mathur, K.N. and Singh, R. V., 2007. Estimation of losses due to plant parasitic nematodes on different crops in India. Indian J. Nematol., 37: 219220.

Jatala, P., French, E.R. and Gutarra, L., 1975. Interrelationship of Meloidogyne incognita acrita and Pseudomonas solanacearum on potatoes. J. Nematol., 7: 325 .

Kavitha, P.G., Jonathan, E.I. and Nakkeeran,
S., 2012. Effects of crude antibiotic of Bacillus subtilis on hatching of eggs and mortality of juveniles of Meloidogyne incognita. Nematol. Medit., 40: 203206.

Siddiqui, Z.A. and Mahmood, I., 2006. Role of bacteria in the management of plant parasitic nematodes, a review. Bioresour Technol., 69: 167-179.

Ying, H., Chuankun, X., LI, M., Keqin, Z., Chang, Q.D. and Ming, M., 2010 Characterisation of volatiles produced from Bacillus megaterium YFM325 and their nematicidal activity against Meloidogyne incognita. Europian $\mathrm{J}$. Pl. Pathol., 126: 417-422.

Zukerman, B.M. and Esnard, J., 1994. Biological control of plant nematodes current status and hypothesis. Japan. J. Nematol., 24: 1-13.

\section{How to cite this article:}

Mahesha, H.S., N.G. Ravichandra, M.S. Rao, N.C. Narasegowda, Shreeshail Sonyal and Shivalingappa Hotkar. 2017. Bio-efficacy of Different Strains of Bacillus spp. against Meloidogyne incognita under in vitro. Int.J.Curr.Microbiol.App.Sci. 6(11): 2511-2517. doi: https://doi.org/10.20546/ijcmas.2017.611.295 